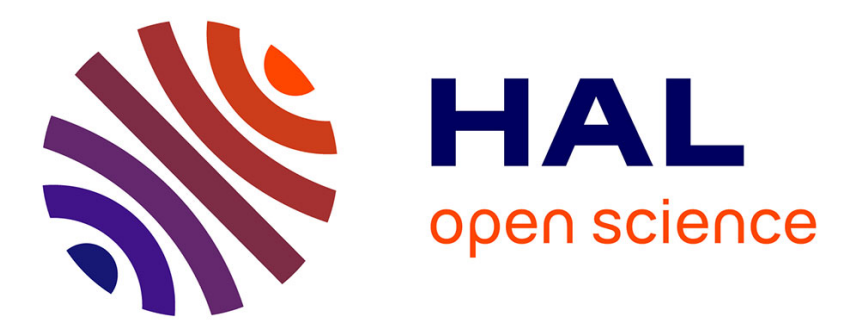

\title{
Acute kidney injury in infective endocarditis: A retrospective analysis
}

A. Gagneux-Brunon, A. Pouvaret, N. Maillard, P. Berthelot, M.F. Lutz, C. Cazorla, C. Tulane, J.F. Fuzellier, P.O. Verhoeven, A. Frésard, et al.

\section{- To cite this version:}

A. Gagneux-Brunon, A. Pouvaret, N. Maillard, P. Berthelot, M.F. Lutz, et al.. Acute kidney injury in infective endocarditis: A retrospective analysis. Médecine et Maladies Infectieuses, 2019, 49, pp.527 533. 10.1016/j.medmal.2019.03.015 . hal-03487662

\section{HAL Id: hal-03487662 \\ https://hal.science/hal-03487662}

Submitted on 21 Dec 2021

HAL is a multi-disciplinary open access archive for the deposit and dissemination of scientific research documents, whether they are published or not. The documents may come from teaching and research institutions in France or abroad, or from public or private research centers.
L'archive ouverte pluridisciplinaire HAL, est destinée au dépôt et à la diffusion de documents scientifiques de niveau recherche, publiés ou non, émanant des établissements d'enseignement et de recherche français ou étrangers, des laboratoires publics ou privés.

\section{(c) (1) $\$$}

Distributed under a Creative Commons Attribution - NonCommerciall 4.0 International 
Version of Record: https://www.sciencedirect.com/science/article/pii/S0399077X18300362

Manuscript_bfb2af7cce3fd3f2dc94d6ef8a800d36

Acute kidney injury in infective endocarditis: a retrospective analysis

Insuffisance rénale aiguë au cours de l'endocardite infectieuse : une analyse rétrospective

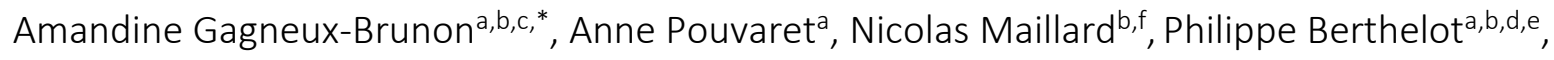
Marie-France Lutz ${ }^{\mathrm{a}, \mathrm{c}}$, Céline Cazorla ${ }^{\mathrm{a}, \mathrm{c}}$, Claire Tulane ${ }^{\mathrm{g}}$, Jean-François Fuzellier ${ }^{\mathrm{h}}$, Paul O. Verhoeven ${ }^{a, b, d}$, Anne Frésard ${ }^{a, c}$, Xavier Duvali, Frédéric Lucht $^{a, b, c}$ and Elisabeth BotelhoNevers $s^{a, b, c}$

${ }^{\text {a }}$ Department of Infectious Diseases, University Hospital of Saint-Etienne, France

${ }^{b}$ GIMAP, EA 3064, Jean Monnet University, University of Lyon, France

${ }^{c}$ CIC 1408 INSERM

d Laboratory of Microbiology and Hygiene, University Hospital of Saint-Etienne, France

e Infection Control Unit, University Hospital of Saint-Etienne, France

${ }^{f}$ Department of Nephrology, Dialysis, Transplantation and Hypertension, University Hospital of Saint-Etienne, France

g Department of Cardiology, University Hospital of Saint-Etienne, France

${ }^{\mathrm{h}}$ Department of Cardiac Surgery, University Hospital of Saint-Etienne, France

'AP-HP, Centre d'Investigation Clinique Inserm 1425, Hôpital Bichat, Université Paris-Diderot, Inserm U1137, Paris, France

*Corresponding author: Amandine Gagneux-Brunon, University Hospital of Saint-Etienne, Avenue Albert Raimond, 42055 Saint-Etienne cedex 2, amandine.gagneux-brunon@chu-stetienne.fr, phone number: +334 771203 56, Fax number: +33 477120443

The first two authors equally contributed to this work. 
Keywords: endocarditis; acute kidney injury; aminoglycosides; vancomycin; prosthetic valve Mots clés : endocardite infectieuse, insuffisance rénale aiguë, aminoglycosides, vancomycine, prothèse valvulaire 


\section{ABSTRACT}

BACKGROUND. ACUTE KIDNEY INJURY (AKI) IS ASSOCIATED WITH HIGH CASE FATALITY IN INFECTIVE ENDOCARDITIS (IE), BUT EPIDEMIOLOGICAL DATA ON THE FREQUENCY OF AKI DURING IE IS SCARCE. WE AIMED TO DESCRIBE THE FREQUENCY AND RISK FACTORS FOR AKI DURING THE COURSE OF IE USING KIDNEY DISEASE: IMPROVING GLOBAL OUTCOMES CONSENSUAL CRITERIA.

METHODS. USING THE FRENCH HOSPITAL DISCHARGE DATABASE (FRENCH ACRONYM PMSI), WE RETROSPECTIVELY REVIEWED THE CHARTS OF 112 PATIENTS PRESENTING WITH A FIRST EPISODE OF PROBABLE OR DEFINITE IE BETWEEN JANUARY 2010 AND MAY 2015.

RESULTS. SEVENTY-SEVEN PATIENTS (68.8\%) DEVELOPED AKI. IN UNIVARIATE ANALYSIS, RISK FACTORS FOR AKI WERE CARDIAC SURGERY FOR IE ( $N=29,37.7 \%$ VS N=4, 1.4\%, $P<0.0005)$, CARDIAC FAILURE ( $\mathrm{N}=29,36.7 \%$ VS $\mathrm{N}=1,2.9 \%, P<0.0005)$, DIABETES MELLITUS $(\mathrm{N}=14,18.2 \%$ VS $N=1,0.9 \%, P=0.034)$, AND PROSTHETIC VALVE IES ( $N=24,31.2 \%$ VS $N=4,11.4 \%)$. NO DIFFERENCES WERE OBSERVED FOR GENTAMICIN EXPOSURE ( $\mathrm{N}=57,64 \%$ VS $\mathrm{N}=32,86.5 \%$, $P=0.286)$. PROSTHETIC VALVE IE, CARDIAC FAILURE, AND VANCOMYCIN EXPOSURE WERE INDEPENDENTLY ASSOCIATED WITH AKI WITH RESPECTIVE ODDS RATIO OF $5.49(95 \% \mathrm{CI}$ 1.92-17.9), 4.37 (95\% Cl 4.37-465.7), AND 1.084 (1.084-16.2). MEAN LENGTH OF HOSPITAL STAY WAS SIGNIFICANTLY LONGER IN PATIENTS PRESENTING WITH AKI THAN IN CONTROLS (RESPECTIVELY $52.4 \pm 22.1$ DAYS VS $39.6 \pm 12.6, P<0.005)$

CONCLUSION. AKI IS VERY FREQUENT DURING IE, PARTICULARLY IN PATIENTS WITH PROSTHETIC VALVE IE, CARDIAC FAILURE, AND THOSE RECEIVING VANCOMYCIN. 


\section{RÉSUMÉ}

INTRODUCTION. L'INSUFFISANCE RENALE AIGUË (IRA) EST ASSOCIEE A UN RISQUE ACCRU DE DECES AU COURS DE L'ENDOCARDITE INFECTIEUSE (EI). LES DONNEES DE FREQUENCE DE L'IRA AU COURS DE L'EI SONT LIMITEES. L'OBJECTIF ETAIT DE DECRIRE LA FREQUENCE ET LES FACTEURS DE RISQUE (FDR) D'IRA AU COURS DE L'EI EN UTILISANT DES CRITERES CONSENSUELS DEFINISSANT ET GRADANT L'IRA.

METHODES. ÉTUDE RETROSPECTIVE DE 112 DOSSIERS D'EI PROBABLES OU CERTAINES (PREMIER EPISODE), SELECTIONNES GRACE AU PROGRAMME DE MEDICALISATION DES SYSTEMES D'INFORMATION ENTRE JANVIER 2010 ET MAI 2015.

RESULTATS. SOIXANTE DIX-SEPT PATIENTS (68,8 \%) ONT DEVELOPPE UNE IRA. EN ANALYSE UNIVARIEE, LES FDR D'IRA ETAIENT RECOURS A LA CHIRURGIE DE L'EI ( $\mathrm{N}=29,37,7 \%$ VS $\mathrm{N}=4$, $1,4 \%, P<0,0005)$, INSUFFISANCE CARDIAQUE ( $N=29,36,7 \%$ VS $N=1,2,9 \%, P<0,0005)$, DIABETE ( $\mathrm{N}=14,18,2 \%$ VS $\mathrm{N}=1,0,9 \%, P=0,034)$, EI SUR VALVE PROTHETIQUE $(\mathrm{N}=24,31,2 \%$ VS $\mathrm{N}=4,11,4 \%$ ). LES PATIENTS AVEC IRA N’ETAIENT PAS PLUS EXPOSES A LA GENTAMICINE QUE LES INDEMNES D'IRA ( $\mathrm{N}=57,64 \%$ VS $\mathrm{N}=32,86,5 \%, P=0,286)$. EN ANALYSE MULTIVARIEE, LES FDR ETAIENT EI SUR VALVE PROTHETIQUE, INSUFFISANCE CARDIAQUE ET EXPOSITION A LA VANCOMYCINE AVEC DES ODDS RATIO RESPECTIFS DE 5,49 (IC $95 \%$ 1,9217,9), 4,37 (IC $95 \%$ 4,37-465,7) ET 1,084 (IC $95 \%$ 1,084-16,2). LA DUREE MOYENNE DE SEJOUR HOSPITALIER ETAIT ALLONGEE CHEZ LES PATIENTS AVEC IRA $(52,4 \pm 22,1$ JOURS VERSUS $39,6 \pm 12,6, P<0,005)$.

CONCLUSION. L'IRA EST UNE COMPLICATION FREQUENTE DE L'EI, PARTICULIEREMENT CHEZ LES PORTEURS DE PROTHESE VALVULAIRE ET EN CAS D' INSUFFISANCE CARDIAQUE. 


\section{INTRODUCTION}

INFECTIVE ENDOCARDITIS (IE) IS A RARE DISEASE WITH AN ESTIMATED INCIDENCE OF 32.4 PER MILLION INHABITANTS IN FRANCE AND 127 PER MILLION INHABITANTS IN THE UNITED STATES [1,2]. THE IN-HOSPITAL CASE FATALITY REMAINS HIGH, RANGING FROM APPROXIMATELY 15\% TO 23\% OF CASES [1,2]. ACUTE KIDNEY INJURY (AKI) IS ONE OF THE FACTORS INDEPENDENTLY ASSOCIATED WITH DEATH [2]. SINCE OSLER'S ERA, CLINICIANS KNOW THAT THE KIDNEY MAY BE INVOLVED DURING THE COURSE OF IE [3]. HOWEVER, IERELATED GLOMERULONEPHRITIS HAS BECOME A RARE CONDITION [4]. OTHER FACTORS SUCH AS SEPTIC SHOCK, HEART FAILURE, ANTIBIOTIC NEPHROTOXICITY, AND THE USE OF IODINE CONTRAST AGENTS MAY CONTRIBUTE TO AKI IN PATIENTS ADMITTED FOR IE [5].

FEW STUDIES HAVE EVALUATED THE INCIDENCE OF AKI DURING THE COURSE OF IE. IN THE RECENT GUIDELINES OF THE EUROPEAN SOCIETY OF CARDIOLOGY, THE CHAPTER DEALING WITH AKI - REFERRED TO AS ACUTE RENAL FAILURE - REPORTS THAT 6-30\% OF PATIENTS DEVELOPED AKI [5]. THE STUDIES CITED IN THESE GUIDELINES DID NOT USE A CONSENSUAL DEFINITION FOR AKI [6-8]. UP TO 2007, THERE WERE NO CONSENSUAL DEFINITIONS FOR AKI. SINCE 2004, DEFINITIONS AND CLASSIFICATIONS (RISK INJURY FAILURE LOSS OF FUNCTION END STAGE KIDNEY DISEASE - RIFLE - AND ACUTE KIDNEY INJURY NETWORK - AKIN - CRITERIA) HAVE BEEN DEVELOPED [9]. THE ABSENCE OF CLEAR AND CONSENSUAL DEFINITIONS FOR AKI MAY IN PART EXPLAIN THE LACK OF EPIDEMIOLOGICAL DATA ABOUT ITS FREQUENCY DURING THE COURSE OF IE. IN 2012, THE KIDNEY DISEASE: IMPROVING GLOBAL OUTCOMES (KDIGO) ORGANIZATION PUBLISHED GUIDELINES FOR THE DIAGNOSIS AND MANAGEMENT OF AKI, WITH A CONSENSUAL DEFINITION DEVELOPED FROM RIFLE AND AKIN CRITERIA [10]. USING THE AKIN CLASSIFICATION - A VERY SIMILAR CLASSIFICATION TO KDIGO'S - A FRENCH STUDY 
IDENTIFIED AKI IN AROUND 60\% OF PATIENTS [11]. HOWEVER, ONLY PATIENTS WHO UNDERWENT CARDIAC SURGERY FOR IE AND WERE ADMITTED TO AN INTENSIVE CARE UNIT WERE INCLUDED [11]. AS THE RATE OF SURGERY FOR IE IS HIGHLY VARIABLE, RANGING FROM 10\% TO 45\% [1,2], THESE RESULTS PROBABLY DO NOT REFLECT THE FREQUENCY OF AKI IN ALL PATIENTS HOSPITALIZED FOR IE.

THE AIMS OF OUR STUDY WERE TO EVALUATE THE FREQUENCY OF AKI IN PATIENTS HOSPITALIZED FOR IE, TO MEASURE THE IMPACT OF AKI ON OUTCOME OF IE, AND TO IDENTIFY RISK FACTORS FOR AKI IN PATIENTS ADMITTED FOR IE TO AN INFECTIOUS DISEASE DEPARTMENT.

\section{MATERIALS AND METHODS}

\subsection{STUDY POPULATION}

ALL PATIENTS PRESENTING WITH IE HOSPITALIZED IN THE INFECTIOUS DISEASE DEPARTMENT AT THE UNIVERSITY HOSPITAL OF SAINT-ETIENNE, FRANCE, FROM JANUARY 2010 TO MAY 2015, WERE SCREENED. PATIENTS WERE SELECTED RETROSPECTIVELY, USING THE FRENCH HOSPITAL DISCHARGE DATABASE (FRENCH ACRONYM PMSI), FROM CHARTS WITH A DISCHARGE DIAGNOSIS OF IE. THE PMSI DATABASE USES THE WORLD HEALTH ORGANIZATION INTERNATIONAL CLASSIFICATION OF DISEASES CODES, 10 ${ }^{\text {TH }}$ REVISION, 2010 VERSION. AFTER REVIEW OF MEDICAL CHARTS, ONLY DEFINITE AND PROBABLE IE CASES, IDENTIFIED BY THE MODIFIED DUKE CRITERIA [12] WERE RETAINED. CASES OCCURRING IN PATIENTS ON CHRONIC DIALYSIS WERE EXCLUDED. IN PATIENTS PRESENTING WITH CHRONIC KIDNEY DISEASE, THE LAST SERUM CREATININE VALUE AVAILABLE BEFORE HOSPITALIZATION WAS COLLECTED IF AVAILABLE IN MEDICAL CHARTS. FOR PATIENTS HAVING MORE THAN ONE EPISODE OF IE DURING THE STUDY PERIOD, ONLY THE FIRST 
EPISODE WAS RETAINED. AS SOON AS THE DIAGNOSIS OF IE WAS SUSPECTED, ALL EPISODES TREATED IN OUR DEPARTMENT OF INFECTIOUS DISEASES WERE MANAGED IN ACCORDANCE WITH THE 2009 EUROPEAN SOCIETY OF CARDIOLOGY GUIDELINES ON THE PREVENTION, DIAGNOSIS, AND TREATMENT OF INFECTIVE ENDOCARDITIS [13]. TROUGH SERUM CONCENTRATIONS OF VANCOMYCIN AND GENTAMICIN WERE MONITORED THREE TIMES A WEEK, AS USUAL IN OUR DEPARTMENT. OUR TARGET VANCOMYCIN TROUGH CONCENTRATION WAS 10-20 MG/L.

\subsection{DATA COLLECTION}

EPIDEMIOLOGICAL, CLINICAL, AND BIOLOGICAL DATA WAS RETROSPECTIVELY COLLECTED USING A STANDARDIZED CASE REPORT FORM. THE FOLLOWING DATA WAS COLLECTED: AGE, SEX, PREDISPOSING HEART CONDITION (PROSTHETIC VALVE, CARDIAC DEVICE), CHARLSON COMORBIDITY INDEX [14], ECHOCARDIOGRAPHIC DATA, MICROBIOLOGICAL DATA, LABORATORY FINDINGS (SERUM CREATININE, PROTEINURIA, URINE CYTOLOGY, PATHOLOGICAL FINDINGS), SURGICAL TREATMENT, LENGTH OF STAY, DAY OF AKI ONSET, AND VITAL STATUS.

\subsection{OUTCOME MEASURE}

OUR AIM WAS TO EVALUATE THE FREQUENCY OF AKI IN PATIENTS ADMITTED FOR IE IN OUR DEPARTMENT. PATIENTS MIGHT BE ADMITTED IMMEDIATELY, AFTER AN INTENSIVE CARE UNIT STAY, OR AFTER CARDIAC SURGERY. WE USED THE SERUM CREATININE CRITERIA DEVELOPED BY THE KDIGO ORGANIZATION [10] TO DEFINE AND STAGE AKI (TABLE 1), AS URINE OUTPUT WAS RARELY AVAILABLE IN MEDICAL RECORDS. GLOMERULAR FILTRATION RATE (GFR) AT ADMISSION WAS ESTIMATED WITH THE EQUATION BASED ON SERUM 
CREATININE DEVELOPED BY THE CHRONIC KIDNEY EPIDEMIOLOGY GROUP [15]. FOR EACH PATIENT, THE STAGE OF AKI WAS DEFINED WITH THE HIGHEST LEVEL OF SERUM CREATININE.

\subsection{ETHICS}

THE STUDY PROTOCOL COMPLIES WITH THE ETHICAL GUIDELINES OF THE 1975 DECLARATION OF HELSINKI AS REFLECTED IN AN APPROVAL BY THE ETHICAL COMMITTEE OF SAINT-ETIENNE UNIVERSITY HOSPITAL, IRBN 722015/CHUSTE.

\subsection{STATISTICAL ANALYSIS}

QUANTITATIVE VARIABLES WERE EXPRESSED AS MEAN \pm STANDARD DEVIATION, OR AS MEDIAN WITH INTERQUARTILE RANGE (IQR) AS APPROPRIATE. QUALITATIVE VARIABLES WERE EXPRESSED BY FREQUENCY AND PERCENTAGE. CASES OF IE WERE DIVIDED FOR COMPARISON INTO TWO GROUPS: THOSE WITH AKI (AKI+) AND THOSE WITHOUT AKI (AKI-). CONTINUOUS VARIABLES WERE COMPARED USING THE T-TEST; CATEGORICAL VARIABLES WERE COMPARED USING THE CHI SQUARE TEST OR FISHER'S EXACT TEST. EACH POTENTIAL EXPLANATION VARIABLE WAS THEN TESTED UNDER UNIVARIATE LOGISTIC REGRESSION TO ASSESS ITS ABILITY TO PREDICT AKI. ONLY FACTORS PRESENT BEFORE AKI ONSET WERE ANALYZED AS POTENTIAL RISK FACTORS FOR AKI. A MULTIVARIATE LOGISTIC REGRESSION MODEL WAS BUILT IN A BACKWARD MANNER, DISCARDING STEP BY STEP THE LESS SIGNIFICANT VARIABLE TO FINALLY ACHIEVE A MINIMAL VALUE OF AKAIKE INFORMATION CRITERION. THE MODEL'S GOODNESS OF FIT WAS EVALUATED BY HOSMER-LEMESHOW TEST AND MACFADEN PSEUDOR ${ }^{2}$. A P VALUE <0.05 WAS CONSIDERED STATISTICALLY SIGNIFICANT FOR ALL TESTS. STATISTICAL ANALYSES WERE PERFORMED USING SPSS SOFTWARE VERSION 
24 (IBM SPSS STATISTICS 24.0, ARMONK, NEW YORK, NY) AND R STATISTICAL SOFTWARE (FOUNDATION FOR STATISTICAL COMPUTING, VIENNA, AUSTRIA).

\section{RESULTS}

\subsection{GENERAL CHARACTERISTICS OF IE PATIENTS}

AMONG THE 218 PATIENTS TREATED FOR IE IN OUR HOSPITAL DURING THE STUDY PERIOD, 125 (57.3\%) WERE HOSPITALIZED IN OUR INFECTIOUS DISEASE DEPARTMENT. AFTER ANALYSIS OF THE MEDICAL RECORDS, 121 CASES WERE RETAINED AS DEFINITE OR PROBABLE IE. AS ONLY THE FIRST EPISODE OF IE WAS RETAINED FOR EACH PATIENT, 112 PATIENTS WITH IE HOSPITALIZED IN THE INFECTIOUS DISEASE DEPARTMENT WERE ASSESSED (51.3\%). AMONG THEM, 93 PATIENTS (83\%) HAD DEFINITE IE WHILE 19 (17\%) HAD PROBABLE IE DIAGNOSIS. GENERAL AND CLINICAL CHARACTERISTICS OF PATIENTS ARE DETAILED IN TABLE 2. EIGHTY-TWO (73.2\%) PATIENTS WERE MEN. MEDIAN AGE WAS 67.5 YEARS (MEAN 64 YEARS, RANGE 18-85, IQR 60-82.3). MEAN CHARLSON COMORBIDITY INDEX WAS $3.91 \pm 2.47$. IE OCCURRED ON A PROSTHETIC VALVE IN 28 CASES (25\%), INCLUDING 11 AND 17 MECHANICAL AND BIOLOGICAL VALVES, RESPECTIVELY. TWELVE PATIENTS (10.7\%) WERE ADMITTED WITH SEPTIC SHOCK (AND HOSPITALIZED IN THE ICU, BEFORE BEING HOSPITALIZED IN THE INFECTIOUS DISEASE DEPARTMENT), AND 30 (26.8\%) DEVELOPED ACUTE HEART FAILURE. FIFTY-FOUR PATIENTS FULFILLED SURGICAL GUIDELINES CRITERIA; HOWEVER, DUE TO COMORBIDITIES, ONLY 33 (29.5\% OF THE ENTIRE POPULATION) HAD VALVE REPLACEMENT SURGERY DURING THE INITIAL PHASE OF IE TREATMENT. AT ADMISSION, MEAN SERUM CREATININE WAS $104.8 \pm 59 \mu \mathrm{MOL} / L$ AND MEAN GFR WAS 72.2 $\pm 26.3 \mathrm{ML} / \mathrm{MIN} / 1.73 \mathrm{M}^{2}$. THE IN-HOSPITAL CASE FATALITY WAS 9.8\%. 


\subsection{ACUTE KIDNEY INJURY}

SEVENTY-SEVEN IE PATIENTS (68.8\%) DEVELOPED AKI ACCORDING TO KDIGO CRITERIA DURING THE HOSPITALIZATION. THIRTY-SEVEN (48.1\%) DEVELOPED AKI STAGE 1, 19 (24.7\%) DEVELOPED AKI STAGE 2, AND 21 (27.3\%) DEVELOPED AKI STAGE 3. THE MEDIAN TIME BETWEEN HOSPITAL ADMISSION AND AKI WAS 25 DAYS (IQR 26 DAYS, 0-90 DAYS). KIDNEY BIOPSIES WERE PERFORMED IN THREE PATIENTS: ONE DEMONSTRATING ENDOCAPILLARY GLOMERULONEPHRITIS WITH C3 DEPOSIT, TWO DEMONSTRATING ACUTE TUBULOINTERSTITIAL NEPHRITIS. ONE PATIENT DEVELOPED CRYSTALLURIA DUE TO AMOXICILLIN.

\subsection{RISK FACTORS FOR AKI DURING IE TREATMENT}

AMONG PATIENTS WITH AKI, 66 PATIENTS (85.7\%) HAD DEFINITE IE AND 11 PATIENTS (14.3\%) HAD PROBABLE IE. IE OCCURRED ON PROSTHETIC VALVES IN 24 PATIENTS WITH AKI (31.2\%). THE GROUP OF PATIENTS WHO DEVELOPED AKI WAS COMPARED WITH THE GROUP OF PATIENTS WHO DID NOT (TABLE 3). IN UNIVARIATE ANALYSIS, FACTORS SIGNIFICANTLY ASSOCIATED WITH AKI WERE IE LOCALIZATION, PROSTHETIC VALVE IE, CARDIAC SURGERY FOR IE, AND ACUTE CARDIAC FAILURE. OF THE 17 PATIENTS WHO RECEIVED VANCOMYCIN, 14 DEVELOPED AKI. THE IODINE EXPOSURE PER PATIENT DID NOT DIFFER BETWEEN THE TWO GROUPS. IN MULTIVARIATE ANALYSIS, PROSTHETIC VALVE IE, ACUTE CARDIAC FAILURE, AND VANCOMYCIN EXPOSURE WERE INDEPENDENTLY ASSOCIATED WITH AKI (AFTER ADJUSTMENT ON AGE, DIABETES MELLITUS, IE LOCALIZATION, AND EXPOSURE TO IODINE CONTRAST AGENTS). THE RESULTS OF THE UNIVARIATE AND MULTIVARIATE ANALYSES ARE DETAILED IN TABLE 4. IN THE 33 PATIENTS WHO UNDERWENT CARDIAC SURGERY FOR IE, 29 (87.8\%) DEVELOPED AKI AND AKI 
OCCURRED AFTER CARDIAC SURGERY IN 23 (79.1\%) OF THEM. NO SIGNIFICANT DIFFERENCE WAS OBSERVED BETWEEN MECHANICAL AND BIOLOGICAL PROSTHESIS.

\subsection{CONSEQUENCES OF AKI DURING IE TREATMENT}

AMONG PATIENTS WITH AKI, THE IN-HOSPITAL CASE FATALITY WAS 13\% (10/77) WHEREAS CASE FATALITY IN PATIENTS WITHOUT AKI WAS $2.9 \%(1 / 35)(P=0.168)$. MEAN LENGTH OF STAY WAS $52.4 \pm 22.1$ DAYS IN PATIENTS WITH AKI AND $39.6 \pm 16.3$ IN PATIENTS WITHOUT AKI ( $P=0.007)$; THE DIFFERENCE REMAINED SIGNIFICANT AFTER ADJUSTMENT FOR SURGERY. RENAL REPLACEMENT THERAPY WAS REQUIRED IN THREE PATIENTS. DOSING ADJUSTMENTS FOR ANTIMICROBIALS WERE REQUIRED IN 18 (21.3\%) PATIENTS, CHANGES IN ANTIMICROBIAL REGIMEN WERE REQUIRED IN 17 (21.5\%) PATIENTS, AND ANTIMICROBIALS WERE DISCONTINUED BEFORE THE SCHEDULED DATE IN 15 PATIENTS (19\%) DUE TO AKI.

\section{DISCUSSION}

OUR STUDY AIMED TO EVALUATE THE FREQUENCY, RISK FACTORS, AND OUTCOMES ASSOCIATED WITH AKI DURING THE COURSE OF IE. LITTLE DATA IS AVAILABLE ON AKI EPIDEMIOLOGY DURING IE. USING CONSENSUAL CRITERIA FOR AKI DIAGNOSIS, WE OBSERVED A HIGH FREQUENCY (68.7\%) OF AKI DURING IE TREATMENT, ALTHOUGH THE INHOSPITAL CASE FATALITY WAS LIMITED TO 10\% IN OUR STUDY.

THIS FREQUENCY IS MUCH HIGHER THAN PREVIOUSLY OBSERVED $[2,6,7,16]$. MOST PREVIOUS STUDIES USED ABSOLUTE VALUES OF SERUM CREATININE FOR AKI DIAGNOSIS. ABSOLUTE VALUES OF SERUM CREATININE ARE PROBLEMATIC FOR DIAGNOSING AKI [10]. THE USE OF DIFFERENT DIAGNOSTIC CRITERIA MAY PARTLY EXPLAIN THE DIFFERENCE BETWEEN THE INCIDENCE OBSERVED IN OUR STUDY AND IN PREVIOUS STUDIES. THE KDIGO ORGANIZATION HAS DEVELOPED CONSENSUAL DEFINITIONS AND STRATIFICATION FOR AKI 
[10]. WE USED THE CREATININE SERUM CRITERIA OF THE KDIGO CLASSIFICATION BECAUSE URINE OUTPUT DATA WAS LACKING IN MOST PATIENTS' CHARTS. WE ONLY IDENTIFIED TWO OTHER STUDIES USING CONSENSUAL CRITERIA. THE FIRST WAS PERFORMED IN PATIENTS WHO HAD CARDIAC SURGERY FOR IE, AND AKI OCCURRED IN 64\% OF PATIENTS [11], A FREQUENCY SIMILAR TO OURS. HOWEVER, THE STUDY POPULATIONS DIFFERED AS THE PREVIOUS STUDY ONLY INCLUDED PATIENTS WITH CARDIAC SURGERY FOR IE IN WHOM AKI MAINLY OCCURRED IN THE POST-OPERATIVE PERIOD, EVEN THOUGH 32.3\% OF PATIENTS DEVELOPED AKI BEFORE CARDIAC SURGERY [11]. IN OUR STUDY, 20\% OF PATIENTS WHO UNDERWENT SURGERY FOR IE HAD DEVELOPED AKI BEFORE CARDIAC SURGERY. THE SECOND STUDY WAS ALSO A MONOCENTER RETROSPECTIVE STUDY, INCLUDING ALL PATIENTS WITH A DIAGNOSIS OF DEFINITE OR PROBABLE IE [17]. IN THIS COHORT, AKI OCCURRED IN 39.8\% OF PATIENTS, A FREQUENCY LOWER THAN IN OUR OBSERVATION. PATIENTS WERE, HOWEVER, SLIGHTLY YOUNGER THAN IN OUR STUDY AND THE CHARLSON COMORBIDITY INDEX WAS POSSIBLY LOWER THAN IN OUR STUDY.

LITERATURE DATA ON RISK FACTORS FOR AKI DURING IE VARIES. SIMILAR TO RICHIE ET AL. [17], WE DID NOT OBSERVE ANY ASSOCIATION BETWEEN AGE AND AKI DURING IE IN CONTRAST WITH PREVIOUS STUDIES $[7,18,19]$. THE FRENCH STUDY PERFORMED IN THE ICU IDENTIFIED AGE >65 YEARS AS A PROTECTIVE FACTOR [11]. OTHER RISK FACTORS FOR AKI DURING IE COURSE, IDENTIFIED IN PREVIOUS STUDIES, WERE THROMBOCYTOPENIA [7], EXPOSURE TO VANCOMYCIN AND/OR AMINOGLYCOSIDES, MULTIPLE SURGERY FOR IE, ANEMIA, AND USE OF IODINE CONTRAST AGENTS [11]. LEGRAND ET AL. OBSERVED AN ASSOCIATION BETWEEN GENTAMICIN EXPOSURE AND POST-OPERATIVE AKI, BUT NOT WITH PRE-OPERATIVE AKI. IN OUR COHORT, WE DID NOT OBSERVE ANY DELETERIOUS EFFECT OF GENTAMICIN ON KIDNEY FUNCTION. HOWEVER, MOST PATIENTS RECEIVED A SHORT 
COURSE (3-5 DAYS) AND A LOW DOSE (3 MG/KG) OF GENTAMICIN. NEPHROTOXICITY WITH LOW DOSE AND SHORT COURSE OF GENTAMICIN IS WIDELY DEBATED $[18,20,21]$. EXTENDED COURSE OF AMINOGLYCOSIDES (>7DAYS) WAS NOT REPORTED AS A RISK FACTOR FOR AKI IN A POPULATION QUITE SIMILAR TO OURS [17]. BY CONTRAST, VANCOMYCIN EXPOSURE WAS FOUND TO BE AN INDEPENDENT RISK FACTOR FOR AKI DURING IE TREATMENT IN OUR STUDY AS WELL AS IN LEGRAND'S STUDY [11]. RITCHIE ET AL. DID NOT OBSERVE ANY ASSOCIATION BETWEEN AKI AND VANCOMYCIN USE WHEN VANCOMYCIN WAS USED ALONE, WHEREAS ITS ASSOCIATION WITH AMINOGLYCOSIDES WAS INDEPENDENTLY ASSOCIATED WITH AKI [17]. THIS PROBABLY MEANS THAT THIS ANTIMICROBIAL WAS USED WITH CAUTION DURING THE COURSE OF IE. AN ASSOCIATION BETWEEN NAFCILLIN AND OXACILLIN USE WAS ALSO FOUND TO BE ASSOCIATED WITH AKI [17]. IN FRANCE, WE USE CLOXACILLIN, WHICH SEEMS TO BE LESS NEPHROTOXIC THAN NAFCILLIN AND OXACILLIN.

STAPHYLOCOCCUS AUREUS IE HAS BEEN REPORTED AS MORE FREQUENTLY ASSOCIATED WITH AKI THAN OTHER BACTERIA $[2,17]$. NO ASSOCIATION WAS OBSERVED IN OUR STUDY, NOR IN MOST OTHER STUDIES AS THEY ALL INCLUDED A SMALL NUMBER OF STAPHYLOCOCCUS AUREUS IES [7,11]. IN CONTRAST WITH PREVIOUS OBSERVATIONS, WE FAILED TO OBSERVE ANY ASSOCIATION BETWEEN EXPOSURE TO IODINE CONTRAST AGENTS AND AKI [11]. HOWEVER, CEREBRAL MRI AND ${ }^{18}$ FDG-PET/CT MIGHT BE PREFERRED TO CONTRAST-ENHANCED CT-SCAN FOR THE DETECTION OF EMBOLIC EVENTS IN PATIENTS AT HIGH RISK OF AKI [5]. FINALLY, ACUTE HEART FAILURE WAS FOUND IN OUR COHORT TO BE STRONGLY ASSOCIATED WITH AKI. THIS ASSOCIATION WAS NOT REPORTED IN PREVIOUS STUDIES. IN THE FRENCH STUDY PERFORMED IN THE ICU, THERE WAS NO DIFFERENCE IN PRE-OPERATIVE LEFT VENTRICULAR EJECTION FRACTION BETWEEN PATIENTS WHO DEVELOPED AKI AND PATIENTS WHO DID NOT [11]. 
AKI IS ASSOCIATED WITH POOR OUTCOMES IN IE. ALTHOUGH MOST PATIENTS WHO DIED (10/11) HAD DEVELOPED AKI, WE ONLY OBSERVED A TREND BUT NO SIGNIFICANT ASSOCIATION BETWEEN AKI AND CASE FATALITY. PREVIOUS STUDIES DEMONSTRATED THAT AKI DURING PRIMARY HOSPITALIZATION FOR IE IS FREQUENTLY ASSOCIATED WITH INHOSPITAL CASE FATALITY [7,19,22,23], MAINLY POST-OPERATIVE AKI [11]. THE ABSENCE OF STATISTICALLY SIGNIFICANT ASSOCIATION IN OUR STUDY MAY BE DUE TO OUR SMALL SAMPLE SIZE AND A LOW CASE FATALITY. NONETHELESS, WE OBSERVED AN INCREASED LENGTH OF HOSPITAL STAY IN PATIENTS WITH AKI. AKI WAS ALSO FOUND TO BE ASSOCIATED WITH A LONGER ICU STAY BUT IT WAS NOT ASSOCIATED WITH A LONGER HOSPITAL STAY IN A PREVIOUS STUDY [11]. OUR COHORT WAS MADE OF $25 \%$ OF PROSTHETIC VALVE ENDOCARDITIS CASES WHEREAS LEGRAND'S COHORT ONLY HAD 17.3\%. PROSTHETIC VALVE IE REQUIRES A LONGER COURSE OF ANTIBIOTICS AND PATIENTS ARE NOT ELIGIBLE FOR OUTPATIENT CARE [5]. MOREOVER, IN OUR CENTER, WE DID NOT PERFORM OUTPATIENT CARE FOR IE AT THE BEGINNING OF THE STUDY PERIOD.

THIS WORK HAS SEVERAL LIMITATIONS AND STRENGTHS. IT IS A MONOCENTER STUDY WITH A RETROSPECTIVE DESIGN. DESPITE A SMALL SAMPLE SIZE, THE CHARTS OF IE PATIENTS WERE SELECTED FROM THE PMSI DATABASE AND ALL CHARTS WERE REVIEWED TO DETECT AKI. THIS METHODOLOGY IS PROBABLY BETTER FOR ASSESSING THE TRUE FREQUENCY OF AKI DURING IE. IN OUR COHORT, AKI WAS UNDER-CODED IN THE PMSI DATABASE; ONLY 19.2\% OF CASES OF IE IN THE PMSI DATABASE WERE CODED WITH AKI (DATA NOT SHOWN). OTHER DIAGNOSIS CODES (GLOMERULONEPHRITIS, OLIGURIA) POSSIBLY ASSOCIATED WITH AKI WERE FOUND IN 6.7\% OF CHARTS. IF WE HAD USED AKI DIAGNOSIS CODE, OUR RESULTS WOULD HAVE BEEN SIMILAR TO THE OBSERVED FREQUENCY OF AKI DURING IE (18\%) IN THE LAST NATIONWIDE STUDY PERFORMED IN THE 
UNITED STATES, INCLUDING 382,153 IE CASES OVER A 12-YEAR PERIOD [2]. THE AUTHORS MENTIONED THAT THE USE OF DIAGNOSTIC CODES OF THE AGENCY FOR HEALTHCARE RESEARCH AND QUALITY'S NATIONWIDE INPATIENT SAMPLE PROBABLY UNDERRECOGNIZED IE COMPLICATIONS DUE TO UNDER-REPORTING BY PHYSICIANS [2]. THESE LIMITS COULD BE EMENDED WITH WIDE PROSPECTIVE STUDIES. OUR RETROSPECTIVE DESIGN AND OUR SMALL SAMPLE SIZE MAY ALSO IN PART EXPLAIN THAT WE FAILED TO IDENTIFY PREVIOUSLY DESCRIBED RISK FACTORS SUCH AS EXPOSURE TO AMINOGLYCOSIDES. MOREOVER, WE DID NOT OBSERVE ANY ASSOCIATION BETWEEN AKI AND CASE FATALITY. THIS ALSO PROBABLY REFLECTS THAT WE DID NOT INCLUDE PATIENTS ONLY MANAGED IN THE ICU. THIS POINT LIMITED THE GENERALIZATION OF OUR RESULTS; HOWEVER, IN MORE SEVERE CASES, THE FREQUENCY OF AKI IS PROBABLY GREATER AS PATIENTS HAD MULTIPLE ORGAN FAILURE.

\section{CONCLUSION}

WE REPORTED THAT AKI WAS A HIGHLY FREQUENT COMPLICATION DURING IE, EVEN IN PATIENTS WHO DID NOT REQUIRE CARE IN THE ICU OR CARDIAC SURGERY. THIS RISK SEEMS FAR HIGHER THAN USUALLY REPORTED. PROSTHETIC VALVE IE, CARDIAC FAILURE, AND VANCOMYCIN EXPOSURE SEEM TO BE PARTICULARLY ASSOCIATED WITH AKI DEVELOPMENT. AKI SEEMS TO BE FREQUENT EVEN BEFORE CARDIAC SURGERY, AND IS PROBABLY ASSOCIATED WITH POORER OUTCOMES IN IE CASES. FURTHER PROSPECTIVE STUDIES ARE REQUIRED TO CONFIRM THIS HIGH FREQUENCY AND TO DETERMINE THE INCIDENCE OF AKI DURING IE MANAGEMENT. INTERVENTIONAL STUDIES ARE REQUIRED TO IMPLEMENT STRATEGIES FOR THE DIAGNOSIS AND PREVENTION OF AKI DURING IE. 


\section{ACKNOWLEDGMENTS}

WE WOULD LIKE TO THANK DR PAUL VERCHERIN FOR THE REQUEST IN THE PMSI DATABASE, ALEXANDRA CAMARGO AND GLYNN THOIRON FOR ENGLISH EDITING.

FUNDING

THIS RESEARCH DID NOT RECEIVE ANY SPECIFIC GRANT FROM FUNDING AGENCIES IN

THE PUBLIC, COMMERCIAL, OR NOT-FOR-PROFIT SECTORS.

DISCLOSURE OF INTERESTS: THE AUTHORS DECLARE NO CONFLICT OF INTERESTS.

CONTRIBUTIONS OF AUTHORS:

CONCEPTION AND DESIGN OF THE STUDY: AGB,AP,EBN, FL

FORMAL ANALYSIS AND INTERPRETATION OF THE DATA, ARTICLE DRAFTING AND REVISING:

$A G B, A P, E B N, P B, N M, F L$

ANALYSIS OF THE DATA: AGB, AP, PB, NM, FL

RESOURCES: JM, JFF, AF, CC, MFL ,CL

VALIDATION: MFL, CC, AF, JFF, JM, CL, POV, XD 


\section{REFERENCES}

[1] SELTON-SUTY C, CELARD M, LE MOING V, DOCO-LECOMPTE T, CHIROUZE C, IUNG B, ET AL. PREEMINENCE OF STAPHYLOCOCCUS AUREUS IN INFECTIVE ENDOCARDITIS: A 1-YEAR POPULATION-BASED SURVEY. CLIN INFECT DIS 2012;54:1230-9. DOI:10.1093/CID/CIS199.

[2] BOR DH, WOOLHANDLER S, NARDIN R, BRUSCH J, HIMMELSTEIN DU. INFECTIVE ENDOCARDITIS IN THE U.S., 1998-2009: A NATIONWIDE STUDY. PLOS ONE 2013;8:E60033. DOI:10.1371/JOURNAL.PONE.0060033.

[3] OSLER W. THE GULSTONIAN LECTURES, ON MALIGNANT ENDOCARDITIS. BR MED J $1885 ; 1: 467-70$

[4] BOILS CL, NASR SH, WALKER PD, COUSER WG, LARSEN CP. UPDATE ON ENDOCARDITIS-ASSOCIATED GLOMERULONEPHRITIS. KIDNEY INT 2015;87:1241-9. DOI:10.1038/KI.2014.424.

[5] MEMBERS AF, HABIB G, LANCELLOTTI P, ANTUNES MJ, BONGIORNI MG, CASALTA J-P, ET AL. 2015 ESC GUIDELINES FOR THE MANAGEMENT OF INFECTIVE ENDOCARDITIS. EUROPEAN HEART JOURNAL. 2015 AUG 29;EHV319.

[6] LE V, GILL S. SERIOUS COMPLICATIONS AFTER INFECTIVE ENDOCARDITIS. DAN MED BULL 2010;57:A4192.

[7] CONLON PJ, JEFFERIES F, KRIGMAN HR, COREY GR, SEXTON DJ, ABRAMSON MA. PREDICTORS OF PROGNOSIS AND RISK OF ACUTE RENAL FAILURE IN BACTERIAL ENDOCARDITIS. CLIN NEPHROL 1998;49:96-101.

[8] MAJUMDAR A, CHOWDHARY S, FERREIRA MA, HAMMOND LA, HOWIE AJ, LIPKIN GW, ET AL. RENAL PATHOLOGICAL FINDINGS IN INFECTIVE ENDOCARDITIS. NEPHROL DIAL TRANSPLANT OFF PUBL EUR DIAL TRANSPL ASSOC - EUR REN ASSOC 2000;15:1782-7.

[9] MEHTA RL, KELLUM JA, SHAH SV, MOLITORIS BA, RONCO C, WARNOCK DG, ET AL., 
ACUTE KIDNEY INJURY NETWORK. ACUTE KIDNEY INJURY NETWORK: REPORT OF AN INITIATIVE TO IMPROVE OUTCOMES IN ACUTE KIDNEY INJURY. CRIT CARE LOND ENGL 2007;11:R31. DOI:10.1186/CC5713.

[10] KDIGO CLINICAL PRACTICE GUIDELINE FOR ACUTE KIDNEY INJURY N.D. HTTP://KDIGO.ORG/HOME/GUIDELINES/ACUTE-KIDNEY-INJURY/ (ACCESSED DECEMBER 7, 2015).

[11] LEGRAND M, PIRRACCHIO R, ROSA A, PETERSEN ML, VAN DER LAAN M, FABIANI J-N, ET AL. INCIDENCE, RISK FACTORS AND PREDICTION OF POST-OPERATIVE ACUTE KIDNEY INJURY FOLLOWING CARDIAC SURGERY FOR ACTIVE INFECTIVE ENDOCARDITIS: AN OBSERVATIONAL STUDY. CRIT CARE LOND ENGL 2013;17:R220. DOI:10.1186/CC13041.

[12] LI JS, SEXTON DJ, MICK N, NETTLES R, FOWLER VG, RYAN T, ET AL. PROPOSED MODIFICATIONS TO THE DUKE CRITERIA FOR THE DIAGNOSIS OF INFECTIVE ENDOCARDITIS. CLIN INFECT DIS OFF PUBL INFECT DIS SOC AM 2000;30:633-8. DOI:10.1086/313753.

[13] HABIB G, HOEN B, TORNOS P, THUNY F, PRENDERGAST B, VILACOSTA I, ET AL. GUIDELINES ON THE PREVENTION, DIAGNOSIS, AND TREATMENT OF INFECTIVE ENDOCARDITIS (NEW VERSION 2009): THE TASK FORCE ON THE PREVENTION, DIAGNOSIS, AND TREATMENT OF INFECTIVE ENDOCARDITIS OF THE EUROPEAN SOCIETY OF CARDIOLOGY (ESC). ENDORSED BY THE EUROPEAN SOCIETY OF CLINICAL MICROBIOLOGY AND INFECTIOUS DISEASES (ESCMID) AND THE INTERNATIONAL SOCIETY OF CHEMOTHERAPY (ISC) FOR INFECTION AND CANCER. EUR HEART J 2009;30:2369-413. DOI:10.1093/EURHEARTJ/EHP285.

[14] CHARLSON M, SZATROWSKI TP, PETERSON J, GOLD J. VALIDATION OF A COMBINED COMORBIDITY INDEX. J CLIN EPIDEMIOL 1994;47:1245-51.

[15] LEVEY AS, STEVENS LA, SCHMID CH, ZHANG YL, CASTRO AF, FELDMAN HI, ET AL., CKD- 
EPI (CHRONIC KIDNEY DISEASE EPIDEMIOLOGY COLLABORATION). A NEW EQUATION TO ESTIMATE GLOMERULAR FILTRATION RATE. ANN INTERN MED 2009;150:604-12.

[16] TAMURA $\mathrm{K}$, ARAI $\mathrm{H}$, YOSHIZAKI T. LONG-TERM OUTCOME OF ACTIVE INFECTIVE ENDOCARDITIS WITH RENAL INSUFFICIENCY IN CARDIAC SURGERY. ANN THORAC CARDIOVASC SURG OFF J ASSOC THORAC CARDIOVASC SURG ASIA 2012;18:216-21.

[17] RITCHIE BM, HIRNING BA, STEVENS CA, COHEN SA, DEGRADO JR. RISK FACTORS FOR ACUTE KIDNEY INJURY ASSOCIATED WITH THE TREATMENT OF BACTERIAL ENDOCARDITIS AT A TERTIARY ACADEMIC MEDICAL CENTER. J CHEMOTHER FLORENCE ITALY 2017:1-7. DOI:10.1080/1120009X.2017.1296916.

[18] COSGROVE SE, VIGLIANI GA, FOWLER VG, ABRUTYN E, COREY GR, LEVINE DP, ET AL. INITIAL LOW-DOSE GENTAMICIN FOR STAPHYLOCOCCUS AUREUS BACTEREMIA AND ENDOCARDITIS IS NEPHROTOXIC. CLIN INFECT DIS OFF PUBL INFECT DIS SOC AM 2009;48:713-21. DOI:10.1086/597031.

[19] BUCHHOLTZ K, LARSEN CT, HASSAGER C, BRUUN NE. IN INFECTIOUS ENDOCARDITIS PATIENTS MORTALITY IS HIGHLY RELATED TO KIDNEY FUNCTION AT TIME OF DIAGNOSIS: A PROSPECTIVE OBSERVATIONAL COHORT STUDY OF 231 CASES. EUR J INTERN MED 2009;20:407-10. DOI:10.1016/J.EJIM.2008.12.017.

[20] BRUSS JB. LACK OF EVIDENCE ASSOCIATING NEPHROTOXICITY WITH LOW-DOSE GENTAMICIN FOR STAPHYLOCOCCUS AUREUS BACTEREMIA AND ENDOCARDITIS. CLIN INFECT DIS OFF PUBL INFECT DIS SOC AM 2009;49:806; AUTHOR REPLY 807-8. DOI:10.1086/605287.

[21] BUCHHOLTZ K, LARSEN CT, HASSAGER C, BRUUN NE. SEVERITY OF GENTAMICIN'S NEPHROTOXIC EFFECT ON PATIENTS WITH INFECTIVE ENDOCARDITIS: A PROSPECTIVE OBSERVATIONAL COHORT STUDY OF 373 PATIENTS. CLIN INFECT DIS OFF PUBL INFECT DIS 
SOC AM 2009;48:65-71. DOI:10.1086/594122.

[22] GÁLVEZ-ACEBAL J, RODRÍGUEZ-BAÑO J, MARTíNEZ-MARCOS FJ, REGUERA JM, PLATA A, RUIZ J, ET AL. PROGNOSTIC FACTORS IN LEFT-SIDED ENDOCARDITIS: RESULTS FROM THE ANDALUSIAN MULTICENTER COHORT. BMC INFECT DIS 2010;10:17. DOI:10.1186/1471-233410-17.

[23] KARTH G, KORENY M, BINDER T, KNAPP S, ZAUNER C, VALENTIN A, ET AL. COMPLICATED INFECTIVE ENDOCARDITIS NECESSITATING ICU ADMISSION: CLINICAL COURSE AND PROGNOSIS. CRIT CARE LOND ENGL 2002;6:149-54. 
Table 1. KDIGO classification for AKI [10].

Tableau 2. Classification de l'insuffisance rénale aiguë selon les recommandations KDIGO (Kidney Diseases Improving Global Outcomes)

\begin{tabular}{lll}
\hline Stage & Serum creatinine & Urine output \\
\hline $\mathbf{1}$ & 1.5-1.9 times baseline or $0.3 \mathrm{mg} / \mathrm{dL}(\geq 26.5 \mu \mathrm{mol} / \mathrm{L})$ & $<0.5 \mathrm{~mL} / \mathrm{kg} / \mathrm{h}$ for $6-12 \mathrm{~h}$ \\
& increase & $<0.5 \mathrm{~mL} / \mathrm{kg} / \mathrm{h}$ for $\geq 12 \mathrm{~h}$ \\
$\mathbf{2}$ & $2-2.9$ times baseline & $<0.3 \mathrm{~mL} / \mathrm{kg} / \mathrm{h}$ for $\geq 24 \mathrm{~h}$ or \\
& 3 times baseline or increase in serum creatinine to & anuria \\
& $\geq 4$ mg/dL $(\geq 353.6 \mu$ mol $/ \mathrm{L})$ or initiation of renal & \\
& replacement therapy or in patients $<18$ years, & \\
& decrease in eGFR to $<35 \mathrm{~mL} / \mathrm{min} / 1.73 \mathrm{~m}^{2}$ &
\end{tabular}

$\overline{\mathrm{AKI}}$, acute kidney injury; GFR, glomerular filtration rate; KDIGO, kidney disease: improving global outcomes. 
Table 3. General characteristics of the study cohort

Tableau 2. Caractéristiques générales des patients de la cohorte

\begin{tabular}{|c|c|}
\hline & $\mathrm{N}=112$ \\
\hline Age (median, range) & $67.5(18-85)$ \\
\hline Male gender & $82(73.2)$ \\
\hline Mean Charlson comorbidity index & 3.91, SD 2.47 \\
\hline \multicolumn{2}{|l|}{ Comorbidities } \\
\hline Congestive heart failure & $11(9.8)$ \\
\hline Cerebrovascular disease & $20(17.9)$ \\
\hline Peripheral vascular disease & 13 (11.6) \\
\hline Hemiplegia & $11(9.8)$ \\
\hline COPD & $10(8.9)$ \\
\hline Connective tissue disease & $4(3.6)$ \\
\hline Diabetes mellitus & $15(13.4)$ \\
\hline Diabetes mellitus with organ damages & $6(5.4)$ \\
\hline Moderate to severe renal disease & $11(9.8)$ \\
\hline Mild liver disease & $3(2.7)$ \\
\hline Moderate to severe liver disease & $3(2.7)$ \\
\hline Tumor in the past 5 years & $12(10.7)$ \\
\hline Metastatic solid tumor & $1(0.9)$ \\
\hline AIDS & $3(2.7)$ \\
\hline Mean eGFR at admission $\left(\mathrm{mL} / \mathrm{min} / 1.73 \mathrm{~m}^{2}\right)$ & 72.2, SD 26.3 \\
\hline Cardiac surgery for IE & $33(29.4)$ \\
\hline Septic shock during the course of IE & $12(10.7)$ \\
\hline Cardiac failure during the course of IE & $30(26.8)$ \\
\hline \multicolumn{2}{|l|}{ Causative pathogens } \\
\hline Staphylococcus aureus & $26(23.2)$ \\
\hline Coagulase-negative staphylococci & $9(8)$ \\
\hline Oral streptococci & $24(21.4)$ \\
\hline
\end{tabular}




\section{IE localization}

Aortic valve

Mitral valve

Tricuspid valve

$7(6.3)$

Multivalvular involvement

\section{Cardiac device-related IE}

Unknown

$4(3.6)$

$\overline{\text { AIDS, acquired immunodeficiency syndrome; COPD, chronic obstructive pulmonary disease; eGFR, estimated }}$ glomerular filtration rate; IE, infective endocarditis; SD, standard deviation.

Continuous variables are expressed as the mean and the standard deviation except for age expressed as median and interquartile range, categorical variables are expressed as number and percentages. Other agents included Candida species, Gram-negative bacilli, Fusobacterium nucleatum, Stenotrophomonas maltophilia, Mycoplasma hominis. 
Table 4. Comparison of IE cases with AKI and without AKI

Tableau 3. Comparaison des cas d'EI avec IRA (AKI +) ou sans IRA (AKI-)

\begin{tabular}{|c|c|c|c|}
\hline & $\mathrm{AKI}+(\mathrm{n}=77)$ & AKI $-(n=35)$ & $p$ value \\
\hline Age & 64.4, SD 14.9 & 62.3, SD 17.4 & 0.556 \\
\hline Male gender & $58(75.3)$ & $24(68.5)$ & 0.454 \\
\hline Diabetes mellitus & $14(18.2)$ & $1(0.9)$ & 0.034 \\
\hline Charlson comorbidity index & $4.14 \pm 2.6$ & 3.40, SD 2.19 & 0.119 \\
\hline Mild to severe renal disease & $9(11.7)$ & $2(5.7)$ & 0.498 \\
\hline eGFR at admission & $65.4(25.2)$ & $87.1(22.6)$ & $<0.0005$ \\
\hline Congestive heart failure & $10(13)$ & $1(2.9)$ & 0.168 \\
\hline Peripheral vascular disease & $10(13)$ & $3(4.6)$ & 0.751 \\
\hline Causative pathogens & & & 0.485 \\
\hline Staphylococcus aureus & $20(26)$ & $6(17.1)$ & \\
\hline Coagulase-negative staphylococci & $8(10.4)$ & $1(2.9)$ & \\
\hline Oral streptococci & $13(16.8)$ & $11(31.4)$ & \\
\hline Streptococcus gallolyticus & $9(11.7)$ & $5(14.3)$ & \\
\hline Enterococcus spp. & $9(11.7)$ & $5(14.3)$ & \\
\hline Negative blood cultures (Bartonella henselae) & $3(3.9)$ & $0(0)$ & \\
\hline Other or not identified & $15(19.5)$ & $6(17.1)$ & \\
\hline \multirow[t]{2}{*}{ Exposure to gentamicin ( $\mathrm{n}$ without missing data $=99$ ) } & $55(83.3)$ & $29(87.9)$ & 0.692 \\
\hline & $29(52.7)$ & $12(41.4)$ & 0.264 \\
\hline
\end{tabular}


Gentamicin exposure $\geq 7$ days

Exposure to vancomycin ( $\mathrm{n}$ without missing data=99)

$14(21.2)$

$3(9.1)$

0.093

Cardiac surgery for IE

$29(37.7)$

$4(11.4)$

$<0.007$

Theorical indications for cardiac surgery

$42(54.5)$

$12(34.3)$

0.046

Types of indications

0.341

Heart failure

$11(14.3)$

$5(14.3)$

Uncontrolled infection

$8(10.4)$

$1(2.9)$

Prevention of embolism

$15(19.5)$

$5(14.3)$

Multiple indications

$8(10.4)$

$2(5.7)$

Septic shock

$10(13)$

$2(5.7)$

0.334

Cardiac failure

$29(37.7)$

$1(2.9)$

$<0.0005$

Duke classification

0.396

Definite IE

$66(85.7)$

$27(77.1)$

Probable IE

$11(14.3)$

8 (22.9)

Prosthetic valve infection

$24(31.2)$

$4(11.4)$

0.033

Mechanical valve

$10(41.7)$

$1(25)$

Biological valve

$14(58.3)$

$3(75)$

IE localization

Aortic

38 (49.4)

15 (42.9)

Mitral

$21(27.3)$

$13(37.1)$ 


\begin{tabular}{|c|c|c|c|}
\hline Tricuspid & $6(7.8)$ & $1(2.9)$ & \\
\hline Multivalvular involvement & $9(11.7)$ & $2(5.7)$ & \\
\hline Cardiac device-related IE & $1(1.3)$ & $2(5.7)$ & \\
\hline Unknown & $2(2.7)$ & $2(5.7)$ & \\
\hline $\begin{array}{l}\text { Number of contrast-enhanced computed tomography/or } \\
\text { angiography }\end{array}$ & 1.95, SD 1.3 & 1.61, SD 0.956 & 0.128 \\
\hline Mean length of stay & 52.36, SD 21.40 & 39.57, SD 12.60 & $<0.005$ \\
\hline In-hospital case fatality & $10(13)$ & $1(2.9)$ & 0.168 \\
\hline
\end{tabular}

AKI, acute kidney injury; eGFR, estimated glomerular filtration rate; IE, infective endocarditis; SD, standard deviation

$p$ values $<0.2$ are reported, continuous variables are expressed as mean and standard deviations, and categorical variables are expressed as $\mathrm{n}$ and percentages. 
Table 5. Risk factors for AKI (after adjustment on age, diabetes, number of contrast-enhanced computed tomography/or angiography)

Tableau 4. Facteurs de risque d'IRA au cours du traitement de l'EI après ajustement sur l'âge, le diabète, le nombre d'examens avec injection de produits de contraste iodés

\begin{tabular}{|c|c|c|c|c|}
\hline & $\begin{array}{c}\text { Univariate OR } \\
(95 \% \mathrm{CI})\end{array}$ & $p$ value & $\begin{array}{l}\text { Multivariate OR }(95 \% \\
\text { CI) }\end{array}$ & $p$ value \\
\hline $\begin{array}{l}\text { Theorical indications } \\
\text { for cardiac surgery }\end{array}$ & $2.36[1.06-5.50]$ & 0.0039 & $0.68[0.175-2.62]$ & NS \\
\hline Acute cardiac failure & $21.31[4.24-388.4]$ & 0.0033 & $4.37[4.37-465.7]$ & 0.003 \\
\hline $\begin{array}{l}\text { Prosthetic valve- } \\
\text { related IE }\end{array}$ & $3.24[1.33-8.81]$ & 0.0138 & 5.49 [1.92-17.9] & 0.0025 \\
\hline $\begin{array}{l}\text { Exposure to } \\
\text { vancomycin }\end{array}$ & $2.19[0.72-8.22]$ & 0.195 & $1.084[1.084-16.2]$ & 0.047 \\
\hline
\end{tabular}

